\title{
KELEMBAGAAN PROGRAM CITARUM HARUM DALAM PENGELOLAAN SUB DAS CIRASEA, CITARUM HULU
}

\author{
Farhana Nurysyifa ${ }^{1 *}$, Kaswanto ${ }^{1 *}$ \\ ${ }^{1}$ Departemen Arsitektur Lanskap, Fakultas Pertanian \\ Institut Pertanian Boogor (IPB), Bogor 16680 \\ * Email: nurysyifarhana@gmail.com ; kaswanto@apps.ipb.ac.id
}

\section{RINGKASAN}

Sub DAS Cirasea merupakan daerah hulu DAS Citarum. Area ini memiliki indeks erosi yang sangat buruk akibat masifnya aktivitas pertanian, sehingga lanskap hutan semakin terancam dari tahun ke tahun. Padahal daerah hulu DAS memiliki peran strategis dalam menjamin kualitas air di daerah yang lebih rendah. Oleh karena itu, penempatan sektor Satgas Kodam III dalam menunjang program Citarum Harum terdapat di beberapa kecamatan di kawasan Sub DAS Cirasea. Namun, pelaksanaan program Citarum Harum yang hanya dibatasi 7 tahun justru menimbulkan persoalan baru terkait keberlanjutan pengelolaan. Untuk itu, penelitian ini bertujuan menyusun rekomendasi untuk mendukung penguatan kelembagaan untuk pengelolaan Sub DAS Cirasea. Kawasan yang menjadi prioritas dalam penempatan sektor khusus menangani permasalahan erosi memiliki beberapa kriteria, seperti status lahan sebagai hutan lindung dan atau hutan konservasi, luasnya area lahan kritis, elevasi di atas $1000 \mathrm{~m}$, dan memiliki topografi curam. Motivasi ekonomi, sebagai salah satu faktor agar masyarakat memiliki inisiatif dalam mengelola sungai, dipengaruhi oleh seberapa pentingnya fungsi sungai sebagai penunjang kehidupan sehari-hari. Analisis SWOT menghasilkan beberapa prioritas rekomendasi, yaitu perlu adanya kepastian koordinasi antarprogram maupun antarsektor secara riil di lapangan dan kepastian pascapanen untuk meningkatkan motivasi petani dalam menanam kopi.

Kata kunci: analisis kelembagaan, indeks erosi, pengelolaan berkelanjutan

\section{PERNYATAAN KUNCI}

- Pengelolaan DAS dalam menanggulangi permasalahan erosi terkesan mengalami simplifikasi, yaitu cukup melakukan kegiatan tanam-menanam. Nyatanya program RHL telah dilaksanakan sejak lama, namun permasalahan erosi tidak kunjung selesai.

- Satgas TNI, sebagai salah satu lembaga program Citarum Harum, memiliki kekonsistenan dalam menjalankan tupoksinya dalam menanggulangi permasalahan erosi meskipun penurunan 
upah dari pusat seringkali mengalami kendala. TNIpun memiliki etos kerja yang tinggi.

- Namun, Satgas TNI seringkali terkesan mengerjakan tupoksi lembaga lain,

- Selain itu, masyarakatpun seringkali menuruti perintah dari TNI mengingat budaya 'feodal' masih melembaga di kehidupan masyarakat.

- Namun koordinasi antara masyarakat dan TNI terkadang mengalami kendala, terutama di daerah yang memiliki konflik lahan yang tinggi di Kecamatan Kertasari, sehingga TNI seringkali bekerja sendiri. Padahal Program Citarum Harum hanya berjalan selama 7 tahun. Jika permasalahan partisipasi masyarakat tidak ditanggulangi, tidak dapat dipastikan apakah mekanisme pengelolaan DAS dapat berjalan secara berkelanjutan.

\section{REKOMENDASI KEBIJAKAN}

- Perlu adanya kepastian koordinasi antarprogram maupun antarsektor secara riil di lapangan.

- Kepastian pascapanen sebagai insentif petani kopi.

- Perlu melibatkan pensiunan TNI dalam mekanisme pengeloalan lingkungan, terutama DAS.

\section{PENDAHULUAN}

Daerah Aliran Sungai (DAS) merupakan salah satu penerapan dari prinsip bioregion dengan mengikuti barisan punggung bukit sebagai tempat awal jatuhnya air ke permukaan bumi. Oleh karena itu, DAS dapat menjadi unit analisis yang tepat dalam penyusunan konsep pengelolaan sumber daya alam untuk menjamin terjaganya kualitas air serta terdistribusinya jumlah air secara optimal. Sehingga air tetap tersedia saat musim kemarau, namun jumlahnya tidak berlebihan saat musim hujan. Menurut Salampessy dan Lidiawati (2017), daerah hulu DAS memiliki fungsi untuk mencegah terjadinya run off hingga ke daerah hilir sehingga banjir dapat dikendalikan, meningkatkan kemampuan infiltrasi sehingga suatu kawasan memiliki kualitas cadangan air tanah yang baik, dan menjadi sumber utama jasa lanskap.

Pembangunan fisik seperti floodway Cisangkuy paket I dan II, Embung Gedebage, Kolam Retensi Cieuteung, pembangunan tunnel Curug Jompong, dan normalisasi Citarum Hulu merupakan salah satu usaha yang dilakukan oleh pemerintah untuk menanggulangi permasalahan Citarum. Namun menurut Bandaragoda (2000), peran kelembagaan diperlukan setelah dilakukan usaha pembangunan fisik untuk mewujudkan pengelolaan DAS yang terpadu. Selain itu, karakteristik alami dan infrastruktur buatan seperti ukuran dan skala, teknologi, dan tujuan akan 
menentukan jenis dan karakter dari lembaga yang didirikan.

Oleh karena itu, pembuat kebijakan memerlukan perluasan lingkup pengetahuan sebagai dasar penyusunan suatu kebijakan yang selama ini cenderung sektoral dalam menyelesaikan suatu permasalahan secara holistik, sehingga bukan hanya terfokus dengan peningkatan kualitas biofisik. Kondisi para stakeholder beserta pengaruh ekonomi, sosial, politik, kebijakan, hukum, dan organisasi pun harus terintegrasi dalam penguatan kelembagaan. Oleh karena itu, penelitian ini bertujuan untuk mengidentifikasi kondisi lanskap yang menjadi faktor penentu terbentuknya suatu kelembagaan di tingkat tapak dan menganalisis relasi beserta permasalahan antara kelembagaan di tingkat pusat dan di tingkat tapak, sehingga akan dihasilkan suatu rekomendasi untuk mendukung penguatan kelembagaan untuk pengelolaan Sub DAS Cirasea dari permasalahan erosi secara berkelanjutan.

\section{METODOLOGI}

\section{Lokasi dan Waktu Penelitian}

Penelitian dilaksanakan pada kecamatan yang ada di Kabupaten Bandung, Provinsi Jawa Barat (Gambar 1) dengan batasan kecamatan yang disesuaikan dengan kawasan dimana masyarakat memiliki inisiatif untukn megikuti program Rehabilitasi Hutan dan Lahan (RHL), memiliki elevasi 700-1200 m dpl, terdapat lahan kritis, dan memiliki tingkat erosi yang buruk. Oleh karena itu, penelitian berfokus pada 6 kecamatan, yaitu Kertasari, Pacet, Arjasari, Ciparay, Ibun, dan Paseh yang tersaji pada Gambar 2.
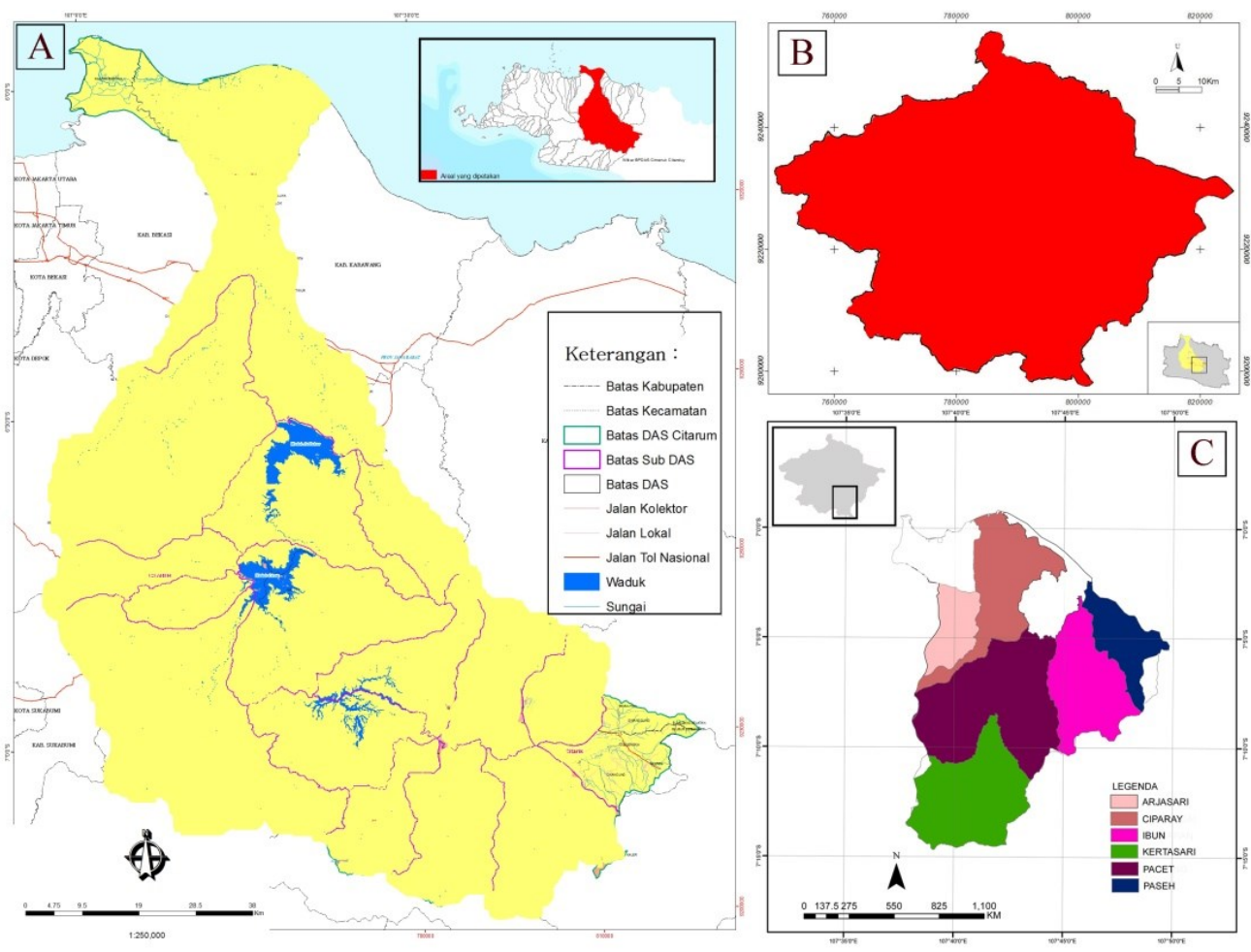
Gambar 1. Lokasi penelitan

(a) Peta Jawa Barat dan Banten; (b) Peta DAS Citarum;

(c) Peta Kabupaten; dan (d) Peta Sub DAS Cirasea
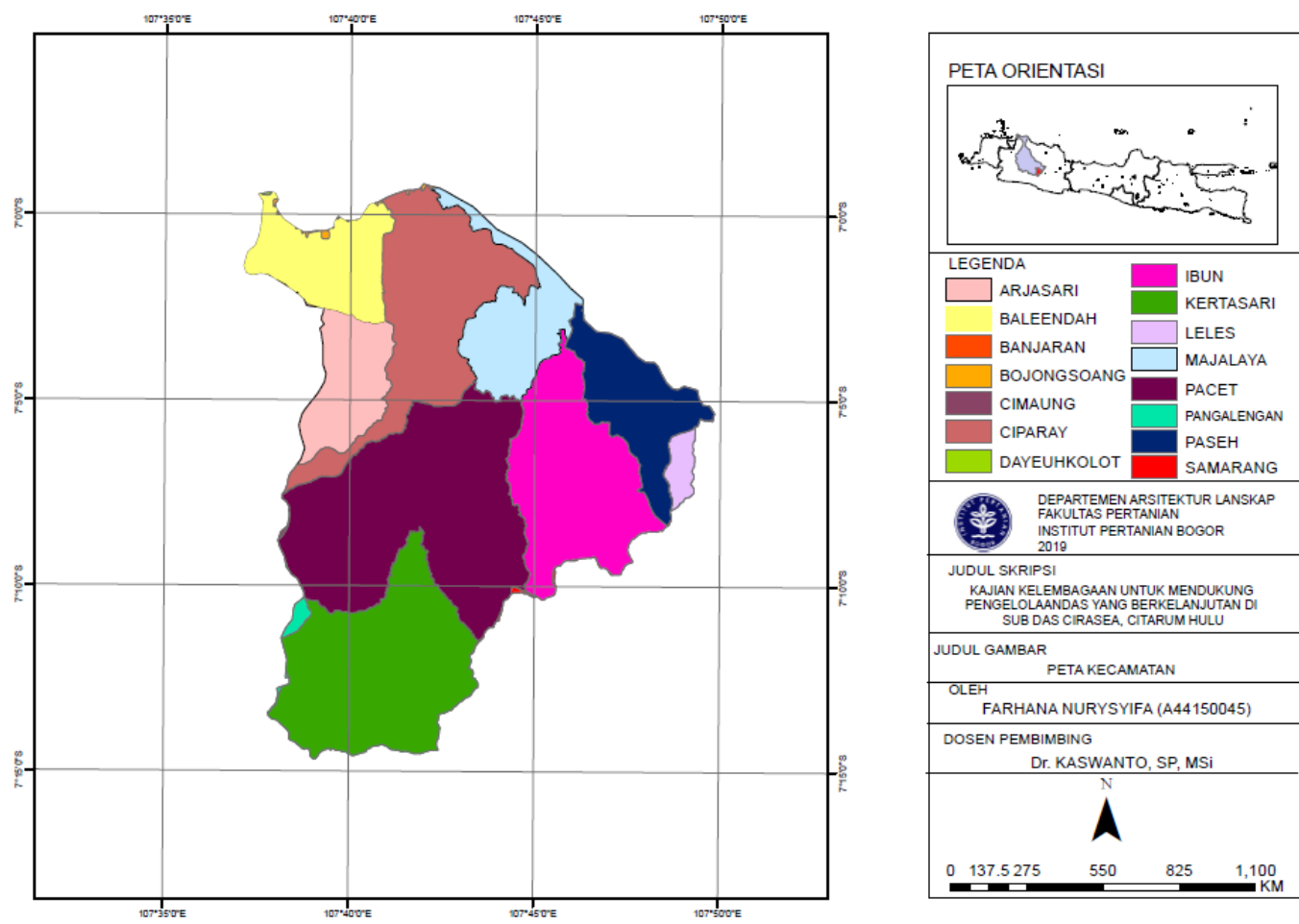

Gambar 2. Peta Kecamatan di kawasan Sub DAS Cirasea

(Sumber: BPDASHL dan BIG)

\section{Metode Penelitian}

Metode yang digunakan dalam studi ini mengacu pada proses analisis kelembagaan dalam mendukung penyusunan rekomendasi kelembagaan oleh Bandaragoda (2000) yang telah dimodifikasi dengan tujuan merumuskan suatu rekomendasi kelembagaan Sub DAS Cirasea dengan menggunakan Geographic Information System (GIS), Analisis Regresi Logistik, Analisis Stakeholder, Analisis Kelembagaan, dan rekomendasi yang berasal dari analisis sebelumnya akan dianalisis dengan menggunakan SWOT.

\section{Tahap Persiapan}

Tahap persiapan yang dilakukan meliputi penyusunan makalah dan proposal penelitian, penyusunan lembar kuisioner, daftar pertanyaan untuk wawancara mendalam, menetapkan sasaran pengambilan sampel dan instansi terkait sesuai dengan batasan dan lingkup penelitian, dan persiapan teknis berupa persiapan alat dan bahan penelitian untuk mengumpulkan informasi dan mengolah data.

\section{Tahap Inventarisasi}


Pengumpulan data primer dilakukan dengan cara groundcheck dan wawancara dengan 30 orang responden dan 14 orang informan yang relevan. Data sekunder merupakan data yang bersumber dari studi pustaka, yaitu buku, jurnal disertasi penelitian terdahulu, dan data yang diperoleh dari instansi terkait.

\section{Tahap Analisis}

\section{Identifikasi Karakter Fisik Sub DAS Cirasea}

Karakteristik Fisik Sub DAS diidentifikasi terlebih dahulu untuk memberikan gambaran kawasan secara umum dan menjadi dasar kemungkinan motivasi kinerja dari kelembagaaan yang terlibat dalam kegiatan pengurangan erosi. Tahapan ini dilakukan dengan menggunakan bantuan software ArcGIS.

\section{Analisis Faktor Sosial Ekonomi}

Masyarakat yang Mendukung

Pengelolaan Sub DAS menggunakan Analisis Regresi Logistik

Peran masyarakat sangat diperlukan dalam pengelolaan Sub DAS sebagai pihak yang paling paham terhadap permasalahan di tingkat tapak sehingga ada upaya dari pemerintah untuk melakukan sinergisitas dengan masyarakat. Analisis regresi logistik berfungsi untuk mengukur seberapa besar peluang masyarakat dalam mendukung pengelolaan Sub DAS $(\mathrm{P}=1)$, dan besar peluang masyarakat tidak mendukung pengelolaan Sub DAS $(\mathrm{P}=0)$ dengan mengikuti sebaran binomial. Model regresi logistik bineri dapat digunakan untuk menganalisis data kategori yang variabel terikatnya merupakan biner dan variabel bebasnya bersifat kontinyu atau kategori. Perbandingan antara probabilitas suatu peristiwa dengan probabilitas tidak terjadinya suatu peristiwa dalam model disebut odds/ resiko. Semakin besar nilai odds, maka terjadi kecenderungan minat masyarakat terhadap usaha pengelolaan Sub DAS. Pengambilan data diperoleh dari hasil wawancara terhadap 30 responden. Analisis menggunakan software SPSS dengan model logitnya sebagai berikut:

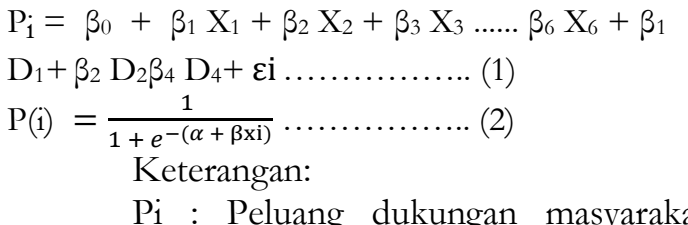
terhadap upaya pengelolaan Sub DAS terhadap ancaman erosi

( 1 = opsi mendukung pengeloaan, $0=$ tidak mendukung pengelolaan)

$\beta 0$ : intersep

$\mathrm{X} 1$ : Pengetahuan tentang rehabilitasi DAS $(1=$ mengerti, $0=$ tidak mengerti $)$

$\mathrm{X} 2$ : Tingkat keterlibatan warga dalam usaha rehabilitasi DAS $(1=$ terlibat, $0=$ tidak terlibat $)$

D1 : Fungsi Sungai $(1=$ ada, $0=$ tidak ada $)$

D2 : Kondisi kebersihan sungai $(1=$ baik, 0 $=$ buruk)

D3 : Preferensi Pekerjaan $(1=a d a, 0=$ tidak ada)

D4 : Aksesibilitas ( $1=$ sulit, $0=$ tidak sulit $)$

D5 : Potensi gotong royong $(1=\mathrm{ada}, 0=$ tidak ada)

Untuk mencari nilai peluang dari masyarakat yang mendukung upaya pengelolaan Sub DAS menggunakan rumus sebagai berikut: 


$$
P i=\frac{\operatorname{Exp}(\beta 0+\beta 1 \mathrm{X} 1+\beta 2 \mathrm{X} 2+\beta 3 \mathrm{X} 3 \ldots \beta 6 \mathrm{X} 6+\beta 1 \mathrm{D} 1+\beta 2 \mathrm{D} 2+\cdots+\beta 4 \mathrm{D} 4)+\varepsilon \mathrm{i}}{1+\operatorname{Exp}(\beta 0+\beta 1 \mathrm{X} 1+\beta 2 \mathrm{X} 2+\beta 3 \mathrm{X} 3 \ldots \beta 6 \mathrm{X} 6+\beta 1 \mathrm{D} 1+\beta 2 \mathrm{D} 2+\cdots+\beta 4 \mathrm{D} 4)+\varepsilon \mathrm{i}}
$$

3. Analisis Kelembagaan

Analisis kelembagaan dilakukan untuk memahami peranan dan pengaruh para pelaku (actors) dalam proses pencapaian tujuan program yang disajikan dalam bentuk deskriptif.

\section{Rekomendasi Pengelolaan Sub DAS Cirasea}

Metode analisis SWOT digunakan untuk menyusun alternatif strategi pengelolaan Sub DAS Cirasea dari sudut pandang kelembagaan dengan membandingkan faktor internal (Strength dan Weakness) dengan faktor eksternal (Opportunity dan Threat) dan dianalisis secara kuantitatif yang dilakukan dengan cara pembobotan dan pemberian rating.

\section{SITUASI TERKINI}

Secara geografis, Sub DAS Cirasea berada di antara $107^{\circ} 37^{\prime} 49,1747^{\prime \prime}$ BT $107^{\circ} 48^{\prime} 30,8923^{\prime \prime}$ BT dan 6 59' 32,9636" LS - $7^{\circ} 14^{\prime} 35,2305^{\prime \prime}$ LS. Sub DAS Cirasea memiliki banyak kawasan lindung, yaitu Cagar Alam Gunung Malabar, Cagar Alam Papandayan, Taman Wisata Alam Kawah Kemojang dan Gunung Mesigit.

Kualitas DAS pada sebagian besar daerah di Indonesia cenderung menurun dari tahun ke tahun seiring dengan bertambahnya daftar sungai prioritas. DAS Citarum merupakan DAS terpanjang di
Jawa Barat dan memiliki peran strategis dalam mendukung ketahanan energi nasional, namun memiliki status kritis dengan tingkat erosi terbesarnya berada di daerah hulu.

Sub DAS Cirasea yang merupakan bagian dari Citarum Hulu memiliki indeks erosi yang sangat buruk. Menurut Rusdiana (2011), laju erosi yang terjadi pada DAS Ciatrum Hulu rata-rata sebesar 574.16 ton/ha/tahun, sehingga DAS Citarum Hulu didominasi lahan dengan tingkat bahaya erosi sangat berat $(36.87 \%)$ dan berat (21.84\%). Besar pelepasan sedimen yang terjadi akibat kejadian erosi pada kawasan DAS Citarum Hulu yaitu rata-rata sebesar 33.88 ton/ha/tahun dengan pelepasan sedimen maksimum sebesar 1044.55 ton/ha/tahun. Menurut Prastiyo et al, (2017), lahan terbangun tersebut telah mengambil alih lahan agroforestri riparian sungai sebagai salah satu solusi mengurangi dampak dari erosi dan sedimentasi. Dominansi patch permukiman mengindikasikan adanya intervensi aktivitas manusia yang tinggi pada lanskap riparian. Selain itu, praktek penanaman tanaman semusim yang tidak memperhatikan kaidah konservasi dilakukan oleh masyarakat DAS Hulu Citarum sehingga resiko terhadap ancaman erosi semakin meningkat dari tahun ke tahun. 


\section{ANALISIS DAN ALTERNATIF SOLUSI/PENANGANAN \\ Analisis Fisik Sub DAS Cirasea}

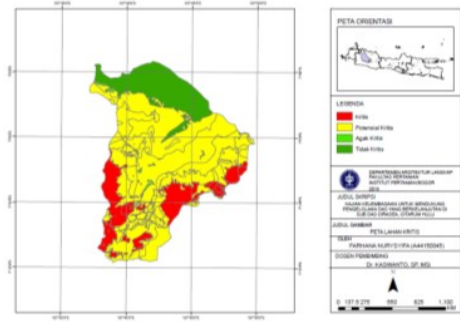

Gambar 3. Peta Lahan Kritis
(Sumber: BPDASHL)

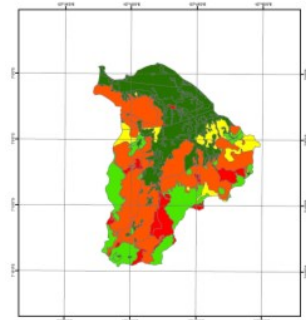

(Sumber: BPDASHL)

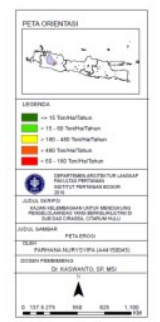

U USLE UL)
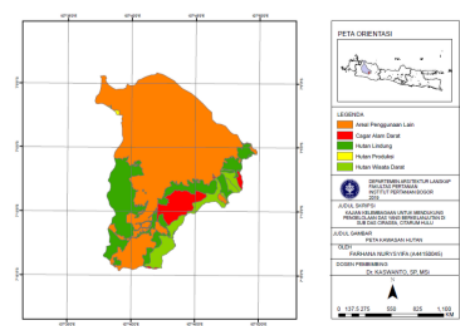

Gambar 5. Kawasan Hutan (Sumber: Ditjen Planologi Kehutanan dan Tata Lingkungan)
Analisis fisik berupa data spasial lahan kritis (Gambar 3) dan erosi (Gambar 4) menunjukkan bahwa kecamatan Kertasari dan Pacet memiliki area kawasan yang paling kritis (> 480 ton/ha/tahun) terluas dibanding kecamatan lainnya. Ditambah lagi kedua kecamatan tersebut berstatus area penggunaan lain yang didominasi oleh private sector dan Hak Guna Usaha (HGU) (ditandai dengan warna orange pada gambar 5) sehingga hal ini menjadi salah satu kendala sulitnya monitoring rehabilitasi daerah hulu DAS. Oleh karena itu, tidak heran jika kawasan tersebut memiliki banyak stakeholder maupun program insentif yang diusung oleh beberapa kementerian yang terlibat untuk mengembalikan daerah hulu sebagai kawasan konservasi dan hutan lindung. Kondisi kelembagaan lokal tiap kecamatan di kawasan Sub DAS Cirasea dijelaskan pada Tabel 3.

Kualitas air yang ditujukan pada Tabel 1 menyatakan adanya nilai yang sifatnya fluktuatif. Nilai $\mathrm{pH}$ yang baik memiliki nilai netral dan lima titik pengambilan kualitas air menunjukkan nilai $\mathrm{pH}$ yang masih termasuk ketegori normal. Nilai BOD yang besar menunjukkan banyaknya oksigen yang diperlukan untuk memecah sampah organik dan hal ini akan memperburuk kualitas air. Hal ini terjadi pada naiknya nilai BOD pada mata air Cisanti tahun 2017 sebesar $<2$ menjadi 2,96 pada tahun 2018. Hal ini terjadi karena adanya penambahan ikan pada situ setelah adanya rehabilitasi situ yang dilakukan oleh satgas kodam. Nilai COD yang kecil menunjukkan berkurangnya oksigen yang diperlukan untuk memecah limbah anorganik dan hal ini akan meningkatkan kualitas air. Hal ini terjadi pada Citarum Majalaya yang terjadi karena adanya usaha agroforestry, sehingga penggunaan pestisida berkurang dan mengurangi kadar kimia yang akan bereaksi dengan oksigen yang terkandung pada air. 
Tabel 1. Kualitas Air Sungai

\begin{tabular}{cccccccccccccccc}
\hline $\begin{array}{c}\text { Para- } \\
\text { meter }\end{array}$ & \multicolumn{3}{c}{ Mata Air Cisanti } & \multicolumn{1}{c}{ Outlet situ Cisanti } & \multicolumn{1}{c}{ BendungWangisagra } & \multicolumn{1}{c}{ Citarum Majalaya } & \multicolumn{3}{c}{ Cirasea cengkong } \\
\hline $\mathrm{pH}$ & 6,6 & 6,6 & 6,5 & 7,6 & 7,3 & 6,6 & 7,9 & 7,9 & 8,4 & 7,8 & 7,7 & 7,4 & 7,9 & 8,2 & 7,8 \\
\hline $\begin{array}{c}\mathrm{BOD} \\
(\mathrm{mg} / \mathrm{l})\end{array}$ & 2,4 & $<2$ & 2,96 & $<2$ & $<2$ & 2,4 & $<2$ & 2,4 & $<2$ & 10 & - & 10 & $<2$ & $<2$ & $<2$ \\
\hline $\begin{array}{c}\mathrm{COD} \\
(\mathrm{mg} / \mathrm{l})\end{array}$ & $<11,5$ & $<2,5$ & 8 & 4,1 & 7 & 16 & 48 & 16 & 9 & 5,2 & 22 & 15 & 47 & 15 & 13 \\
\hline $\begin{array}{c}\mathrm{DO} \\
(\mathrm{mg} / \mathrm{l})\end{array}$ & 9 & 5 & 4,9 & 8 & 9 & 6,97 & 7 & 6,3 & 6,7 & - & 6,8 & 2 & 7 & 12 & 6,2 \\
\hline
\end{tabular}

(sumber: BBWS 2016, 2017, dan 2018)

\section{Analisis Sosial-Ekonomi}

Analisis regresi logistik digunakan untuk mengetahui faktor yang paling signifikan berpengaruh terhadap besarnya peluang masyarakat dalam mendukung pengelolaan Sub DAS. Hasil analisis disajikan pada Tabel 2.

Interpretasi dari hasil Variables in the Equation adalah hanya variabel D2 (fungsi sungai) yang berpengaruh signifikan dengan

Tabel 2. Hasil Variables in the Equation

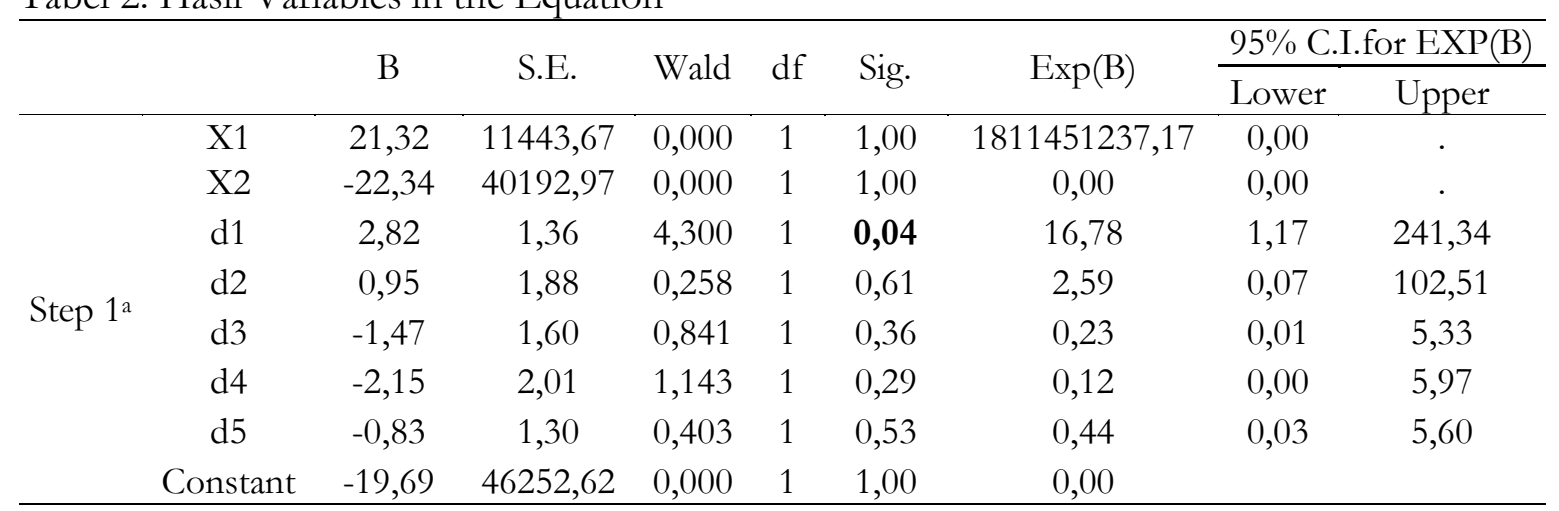

semakin besarnya peluang dan motivasi masyarakat dalam mengelola Sub DAS karena memiliki nilai signifikasi dibawah $5 \%$.

Oleh karena itu, masyarakat yang memang memanfaatkan sungai secara langsung memiiliki peluang yang lebih besar untuk melakukan pengelolaan DAS, misalnya petani.

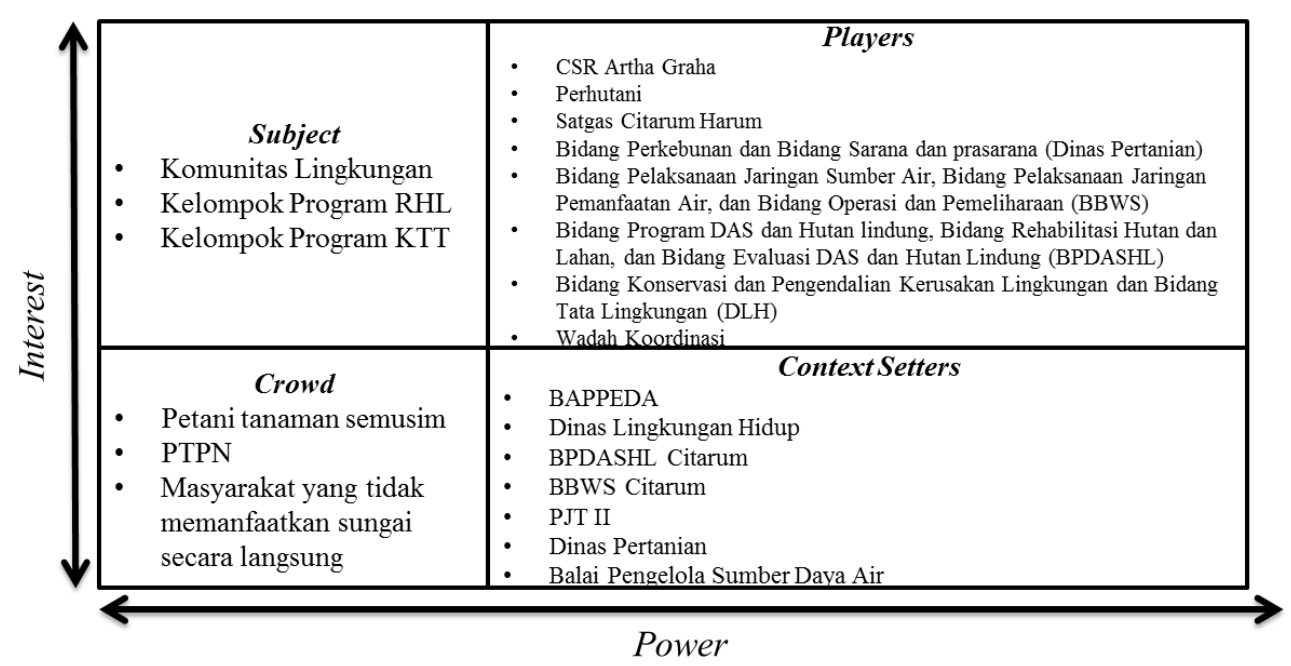

Gambar 6. Analisis Stakeholder 
Tabel 3. Analisis Fisik dan kelembagaan lokal tiap Kecamatan

\begin{tabular}{|c|c|c|c|c|c|c|c|c|}
\hline \multirow[b]{2}{*}{$\begin{array}{c}\mathrm{N} \\
\mathrm{o}\end{array}$} & \multirow[b]{2}{*}{$\begin{array}{l}\text { Keca- } \\
\text { matan }\end{array}$} & \multirow[b]{2}{*}{ Topografi } & \multirow[b]{2}{*}{$\begin{array}{l}\text { Elevasi } \\
(\mathrm{mdpl})\end{array}$} & \multicolumn{3}{|c|}{ Luas Penggunaan Lahan } & \multirow[b]{2}{*}{ Landuse } & \multirow[b]{2}{*}{ Kelembagaan lokal (studi kasus) } \\
\hline & & & & $\begin{array}{l}\text { Sawah } \\
\text { (ha) }\end{array}$ & $\begin{array}{l}\text { Lahan } \\
\text { Pertanian } \\
\text { non } \\
\text { Sawah }\end{array}$ & $\begin{array}{l}\text { Non } \\
\text { Pertanian } \\
\text { (ha) }\end{array}$ & & \\
\hline 1 & Arjasari & $\begin{array}{l}\text { Dataran dan } \\
\text { lereng/punggung } \\
\text { bukit. }\end{array}$ & 744-982 & 1370.6 & 2744 & 820,70 & $\begin{array}{l}\text { - Pepohonan mendominasi kawasan non hutan } \\
\text { sehingga tidak banyak kegiatan penghijauan. } \\
\text { - Sawah berfungsi untuk memenuhi kebutuhan } \\
\text { subsisten masyarakat }\end{array}$ & $\begin{array}{l}\text { Forum lingkungan dibentukan oleh Pemda. Selain itu, } \\
\text { Satgas citarum harum, praktek RHL, dan KTT tidak } \\
\text { ditemukan di kecamatan ini. }\end{array}$ \\
\hline 2 & Ciparay & Dataran & $683-795$ & 2690,96 & $1.350,40$ & 2445,66 & $\begin{array}{l}\text { Kawasan non hutan dengan penggunaan lahan } \\
\text { didominasi oleh lahan pertanian. }\end{array}$ & $\begin{array}{l}\text { Pecinta Alam Lembah caringin (PALEC) merupakan } \\
\text { salah satu komunitas masyarakat pecinta alam di desa } \\
\text { Ciparay yang berfokus pada pembibitan dan } \\
\text { pengolahan pascapanen kopi. }\end{array}$ \\
\hline 3 & Ibun & $\begin{array}{l}\text { Lereng/Punggung } \\
\text { Bukit }\end{array}$ & $700-1200$ & 1484,6 & 2203,3 & 941 & $\begin{array}{l}\text { - Lahan pertanian tanaman semusim dan sawah } \\
\text { - Penghijauan massif dilakukan dengan } \\
\text { penanaman tanaman kopi yang dinaungi oleh } \\
\text { pohon pinus di Desa Laksana dan Ibun. }\end{array}$ & $\begin{array}{l}\text { Kecamatan Ibun masih mengandalkan kekuatan } \\
\text { tokoh dalam melakukan kegiataan penghijauan. } \\
\text { Penanaman pohon masih banyak dilakukan oleh } \\
\text { KTH. Satgas citarum harum tidak ditemukan. }\end{array}$ \\
\hline 4 & Kertasari & $\begin{array}{l}\text { Lereng/Punggung } \\
\text { Bukit }\end{array}$ & $1267-1832$ & 15 & $13.118,75$ & $2.165,18$ & $\begin{array}{l}\text { - Hanya desa Tarumajaya yang memiliki status } \\
\text { kawasan hutan yang dimiliki oleh perhutani. Desa } \\
\text { lainnya berada diluar kawasan hutan dan } \\
\text { didominasi oleh Hak Guna Usaha (HGU). } \\
\text { - Lahan pertanian didominasi oleh komoditas } \\
\text { kentang meskipun kawasan tersebut memiliki } \\
\text { topografi yang curam. } \\
\text { - Penghijauan massif dilakukan karena kecamatan } \\
\text { Kertasari diharapkan dapat menjadi kawasan } \\
\text { dengan daya infiltrasi air yang tinggi dengan } \\
\text { adanya hutan lindung dan terdapat daerah mata air } \\
\text { utama Citarum sebagai area konservasi, yaitu Situ } \\
\text { Cisanti. }\end{array}$ & $\begin{array}{l}\text { Kecamatan Kertasari memiliki stakeholder yang paling } \\
\text { banyak. Hal ini terjadi akibat peran konservasi yang } \\
\text { harus diemban oleh daerah ini sehingga } \\
\text { mempengaruhi serapan dana dari pemerintah. Salah } \\
\text { satu komunitas yang terdapat dalam kawasan ini } \\
\text { adalah Institut Gunung Wayang (IGW) yang } \\
\text { berfokus pada inovasi yang dapat meningkatkan } \\
\text { kedaulatan petani. Selain itu, banyak masyarakat yang } \\
\text { tergabung dalam Kelompok Hutan Tani (KTH) } \\
\text { mengikuti program insentif dari kementerian seperti } \\
\text { Rehabilitasi Hutan dan Lahan (RHL), Kredit Tunda } \\
\text { Tebang (KTT), dll. Kawasan inipun menjadi fokus } \\
\text { program Citarum Harum }\end{array}$ \\
\hline 5 & Pacet & $\begin{array}{l}\text { Lereng/Punggung } \\
\text { Bukit }\end{array}$ & $839-1305$ & 3011,28 & $5.816,05$ & 921,62 & $\begin{array}{l}\text {-Desa sukarame, cipeujeuh, maruyung, dan } \\
\text { tanjungwangi merupakan daerah luar kawasan } \\
\text { hutan. Namun landuse Kecamatan Pacet } \\
\text { didominasi oleh areal hutan } \\
\text {-Sawah menjadi representasi aktivitas pertanian } \\
\text { yang paling dominan }\end{array}$ & $\begin{array}{l}\text { - Mayoritas desa umumnya memgandalkan kinerja } \\
\text { Satgas Citarum Harum dalam rehabilitas sungai } \\
\text { - Beberapa kelompok masyarakat Desa Girimulya dan } \\
\text { Sukarame mengikuti program Kredit Tunda Tebang } \\
\text { (KTT) }\end{array}$ \\
\hline 6 & Paseh & $\begin{array}{l}\text { Dataran dan } \\
\text { Lereng/Punggung } \\
\text { Bukit }\end{array}$ & $600-750$ & 1558,49 & & & $\begin{array}{l}\text {-Lahan pertanian tanaman semusim dan sawah } \\
\text {-Permukiman padat terdapat di daerah pasar }\end{array}$ & $\begin{array}{l}\text { tanaman kopi massif dilakukan di Desa Loa dan } \\
\text { Drawati yang didominasi oleh landuse hutan. } \\
\text { Masyarakat yang tergabung dalam Kelompok Tani } \\
\text { Hutan mengiuti program kementerian berupa PBHM }\end{array}$ \\
\hline
\end{tabular}


Tabel 4. Identifikasi Lembaga Pusat

\begin{tabular}{|c|c|c|c|c|c|c|}
\hline No & $\begin{array}{l}\text { Nama } \\
\text { Organisasi }\end{array}$ & $\begin{array}{l}\text { Jenis } \\
\text { Lem- } \\
\text { baga }\end{array}$ & $\begin{array}{l}\text { Dasar } \\
\text { Hukum }\end{array}$ & $\begin{array}{l}\text { Sumber } \\
\text { Dana }\end{array}$ & $\begin{array}{l}\text { Deskripsi Tugas pokok, } \\
\text { fungsi, dan peran } \\
\text { Organisasi }\end{array}$ & Persepsi \\
\hline 1. & $\begin{array}{l}\text { Dinas } \\
\text { Lingkungan } \\
\text { Hidup/ } \\
\text { BPLHD } \\
\text { Kabupaten } \\
\text { Bandung }\end{array}$ & $\begin{array}{l}\text { Pem- } \\
\text { da }\end{array}$ & $105 / 2018$ & APBD & $\begin{array}{l}\text { Operator } \\
\text { Pengendali pencermaran }\end{array}$ & $\begin{array}{l}\text { 1. Konflik dan benturan antara } \\
\text { kepentingan ekonomi dengan } \\
\text { kepentingan pengendalian, } \\
\text { inkonsistensi kebijakan tata ruang } \\
\text { dan penegakkan hukum } \\
\text { 2. Benturan kepentingan di perbatasan } \\
\text { wilayah. }\end{array}$ \\
\hline 2. & BPDASHL & $\begin{array}{l}\text { Peme- } \\
\text { rintah } \\
\text { Pusat }\end{array}$ & $\begin{array}{l}\text { P.10/Menlhk/ } \\
\text { Setjen/OTL.0/ } \\
\text { 1/2016 }\end{array}$ & $\begin{array}{l}\text { APBN } \\
\text { (KLHK) }\end{array}$ & $\begin{array}{l}\text { Developer } \\
\text { Konservasi wilayah Hulu } \\
\text { Sungai }\end{array}$ & $\begin{array}{l}\text { Mengalami benturan kepentingan } \\
\text { dengan sektor pertanian. }\end{array}$ \\
\hline 3. & BBWS & $\begin{array}{l}\text { Peme- } \\
\text { rintah } \\
\text { Pusat }\end{array}$ & $\begin{array}{l}26 / \mathrm{PRT} / \mathrm{M} / 2 \\
006\end{array}$ & $\begin{array}{l}\text { APBN } \\
(\mathrm{PU})\end{array}$ & $\begin{array}{l}\text { Operator } \\
\text { Merencanakan dan } \\
\text { membangun fisik sungai } \\
\text { dan memelihara badan air } \\
\text { di sepanjang sungai. } \\
\text { Regulator } \\
\text { 1. Penetapan Ijin Alokasi } \\
\text { Air } \\
\text { 2. Penetapan tarif: air } \\
\text { baku, tenaga listrik, } \\
\text { pollution fee dan BJPSDA } \\
\text { lainnya } \\
\text { 3. Ijin galian golongan C } \\
\text { (di badan sungai) } \\
\text { Developer } \\
\text { Pembangunan prasarana } \\
\text { pada sungai utama }\end{array}$ & $\begin{array}{l}\text { 1. BBWS berbenturan dengan otonomi } \\
\text { daerah karena batas sungai tidak } \\
\text { sesuai dengan batas administrasi. } \\
\text { 2. Efektivitas fungsi perencanaan dan } \\
\text { pemeliharaan belum tercapai karena } \\
\text { berkaiatan dengan catchment area } \\
\text { yang dikelola oleh instansi lain. } \\
\text { Namun akan ada rencana kolaborasi } \\
\text { dengan BPDSHL terkait } \\
\text { pengukuran aspek hidrologi. }\end{array}$ \\
\hline 4. & $\begin{array}{l}\text { Balai } \\
\text { Pengelolan } \\
\text { Sumber Daya } \\
\text { Air (PSDA) }\end{array}$ & $\begin{array}{l}\text { Pemerint } \\
\text { ah } \\
\text { Daerah }\end{array}$ & & $\begin{array}{l}\text { APBN } \\
\text { (PU) }\end{array}$ & $\begin{array}{l}\text { Operator } \\
\text { Sungai orde } 2 \text { dan } 3 \text { dan } \\
\text { mengelola jaringan irigasi } \\
1000-3000 \text { ha } \\
\text { Regulator } \\
\text { Penetapan rencana taman } \\
\text { dan penetapan RTRW } \\
\text { provinsi } \\
\text { Developer } \\
\text { Pembangunan prasarana } \\
\text { sungai orde } 2 \text { dan } 3\end{array}$ & $\begin{array}{l}\text { Tupoksi sering tumpang tindah } \\
\text { antara BBWS (dibawah kementerian } \\
\text { PU) dengan PSDA, baik dalam } \\
\text { pengelolaan badan air maupun } \\
\text { pembangunan prasarana. }\end{array}$ \\
\hline 5. & $\begin{array}{l}\text { Perum Jasa } \\
\text { Tirta II } \\
\text { (Korporasi) }\end{array}$ & BUMN & $\begin{array}{l}\text { PP No. } 7 \\
\text { Tahun } 2010\end{array}$ & & $\begin{array}{l}\text { Operator } \\
\text { Pengelolaan perasarana } \\
\text { utama alokasi air } \\
\text { Developer } \\
\text { Menjalankan peran CSR di } \\
\text { daerah konservasi Situ } \\
\text { Cisanti yang merupakan } \\
\text { wilayah wewenang } \\
\text { BBKSDA. }\end{array}$ & $\begin{array}{l}\text { 1. Paradoks antara fungsi sebagai } \\
\text { lembaga yang menerapan usaha } \\
\text { konservasi dan bisnis yang } \\
\text { cenderung melakukan kegiatan } \\
\text { eskploitasiSDA } \\
\text { 2. kontradiktif dengan peran } \\
\text { pengelolaan BBWS Citarum yang } \\
\text { berbeda }\end{array}$ \\
\hline 6. & Forum DAS & $\begin{array}{l}\text { Peme- } \\
\text { rintah } \\
\text { pusat }\end{array}$ & $\begin{array}{l}\text { S.652/Menhut } \\
-\mathrm{V} / 2006\end{array}$ & $\begin{array}{l}\text { Suka- } \\
\text { rela } \\
\text { (KLHK) }\end{array}$ & $\begin{array}{l}\text { Wadah koordinasi } \\
\text { pengelolaan DAS, yaitu } \\
\text { organisasi para pemangku } \\
\text { kepentingan yang } \\
\text { terkoordinasi. Kajian, } \\
\text { Koordinasi, dan konsultasi } \\
\text { dalam melakukan } \\
\text { pengelolaan DAS sesuai } \\
\text { dengan prinsip Kordinasi, } \\
\text { Integrasi, Sinergitas, dan } \\
\text { Sinkronisasi (KISS) }\end{array}$ & $\begin{array}{l}\text { Kinerja Forum DAS dianggap belum } \\
\text { efektif karena kelembagaan masih } \\
\text { belum tertata akibat masih terjadi } \\
\text { konflik kepentingan dan tumpang } \\
\text { tindih tupoksi antar sector, pemda, } \\
\text { dan stakeholder lainnya. }\end{array}$ \\
\hline
\end{tabular}

(Sumber: Hasan (2011) dan Raharja (2008)) 
Tabel 5. Identifikasi Lembaga dalam Lingkup Tapak

\begin{tabular}{|c|c|c|c|c|c|c|c|}
\hline Lembaga & Pelaku & K1 & $\mathrm{K} 2$ & K3 & K4 & K5 & K6 \\
\hline \multirow[t]{4}{*}{ Masyarakat } & Pelaksana Kegiatan program RLH (2017) & & $\checkmark$ & $\checkmark$ & $\checkmark$ & $\checkmark$ & \\
\hline & $\begin{array}{l}\text { Pelaksana Kegiatan program Kredit } \\
\text { Tunda Tebang (KTT) }\end{array}$ & & & & & $\checkmark$ & \\
\hline & $\begin{array}{l}\text { Pelaksana Kegiatan Program Citarum } \\
\text { Harum }\end{array}$ & & $\checkmark$ & $\checkmark$ & & $\checkmark$ & \\
\hline & Komunitas lingkungan & & $\checkmark$ & $\checkmark$ & & & \\
\hline \multirow[t]{2}{*}{ Pemerintah Daerah } & Pemerintah Kabupaten & $\checkmark$ & $\checkmark$ & $\checkmark$ & $\checkmark$ & $\checkmark$ & $\checkmark$ \\
\hline & Pemerintah Desa & $\checkmark$ & $\sqrt{ }$ & $\checkmark$ & $\checkmark$ & $\sqrt{ }$ & $\sqrt{ }$ \\
\hline \multirow[t]{2}{*}{ Pengelola Kawasan } & Perhutani $(\mathrm{KPH})$ & & & $\checkmark$ & $\checkmark$ & $\checkmark$ & $\checkmark$ \\
\hline & Perkebunan teh rakyat & & & $\sqrt{ }$ & & & \\
\hline \multirow{2}{*}{$\begin{array}{l}\text { Lembaga Donor } \\
\text { (program CSR) }\end{array}$} & Artha Grha & & $\checkmark$ & $\checkmark$ & & & \\
\hline & Perum Jasa Tirta II & & & $\checkmark$ & & & \\
\hline
\end{tabular}

Ket: K1: Arjasari; K2: Ciparay; K3: Kertasari; K4: Ibun; K5: Pacet; K6: Paseh

\section{Analisis Stakeholder}

Analisis Stakeholder dapat digunakan untuk memahami kepentingan (interest) dan pengaruh (influence) dan bagaimana hal ini dapat mendukung atau mengancam kinerja suatu pengelolaan. Hasil analisis tersaji pada Gambar 6.

\section{Analisis Kelembagaan}

Identifikasi Lembaga Pusat

Identifikasi lembaga yang relevan dalam menanggulangi permasalahan erosi ditingkat tapak disesuaikan dengan rencana aksi DAS Citarum yang telah disahkan oleh Gubernur Jawa Barat dalam Program Citarum Harum. Sehingga perlu mengetahui tupoksi beberapa instansi agar dapat memproyeksikan lembaga mana saja yang terkait dalam menangani masalah erosi. Persepsi yang berkembang di pusat menyatakan bahwa Sungai Citarum dianggap sebagai strategis nasional. Oleh karena itu, Pengeloalan DAS Citarum menjadi wewenang pemerintah pusat. Tupoksi kelembagaan pusat tersaji pada Tabel 4 dan pemetaan stakeholder di tiap kecamatan disajikan pada Tabel 5 .
Sebenarnya tupoksi yang dilakukan antarstakeholder saling terkait, baik pengelolaan Sub DAS yang dilakukan oleh lembagan pusat maupun lembaga lokal. Hubungan antara lembaga pusat dan lokal dapat dijabarkan pada Gambar 7. Menurut Sofhani et al, (2016), pengelolaan sumber daya air DAS Citarum bersifat multi institusi serta latar belakang yang sarat dengan konfik kepentingan, maka fungsi koordinasi ini berperan sangat penting. Kajian tekait pola relasi kuasa pengelolaan hulu Citarum umumnya kurang mengkaji aspek interaksi antar aktor formal maupun informal. Oleh karena itu, kajian terkait pengelolaan DAS umumnya kurang dapat menggambarkan pengaruh dan komunikasi antar aktor dalam pengelolaan DAS. Aspek interaksi antar aktor sebagai implikasi koordinasi antar lembaga yang dijelaskan pada Gambar 8 membuktikan bahwa peran sentral dilakukan oleh DLH, lalu Citarum Harum, dan BBWS dalam pengelolaan Sub DAS Cirasea. Hal ini terjadi karena adanya keterhubungan lintas kelompok aktor yang membuka kesempatan untuk berperan lebih besar dari kewenangan struktural yang membatasi serta wilayah kinerjanya tidak dibatasi oleh wilayah administrasi. 


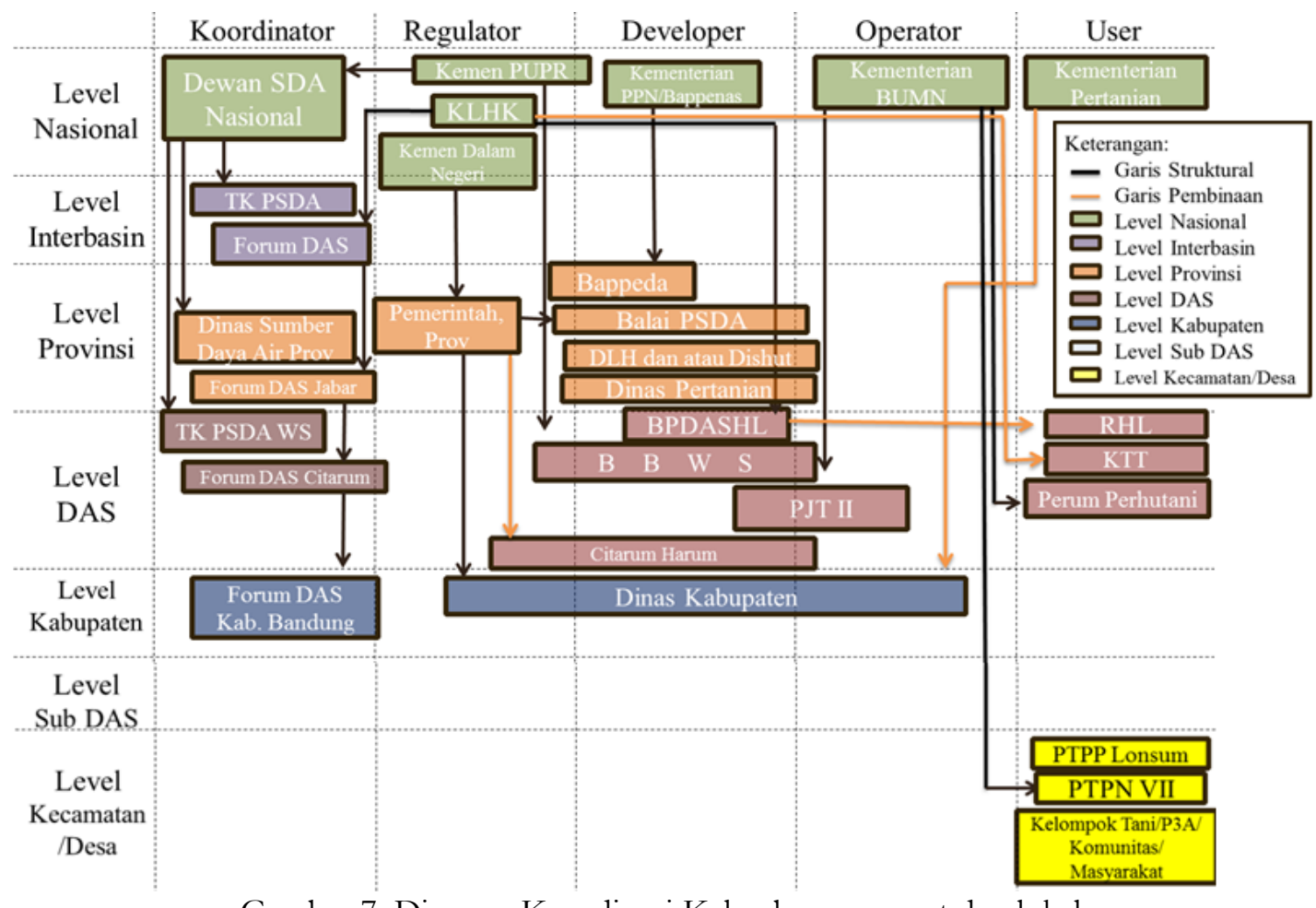

Gambar 7. Diagram Koordinasi Kelembagaan pusat dan lokal

\section{Rekomendasi Kelembagaan Pengelolaan Sub DAS Cirasea}

Rekomendasi Kelembagaan

Pengelolaan SubDAS Cirasea dirumuskan dengan menggunakan metode analisis SWOT. Metode ini dilakukan dengan mewawancarai stakeholder yang terlibat dalam penyelesaian permasalahn erosi untuk menentukan faktor internal dan faktor eksternal beserta tingkat kepentingan masing-masing faktor.

Tabel 6. Penilaian skor faktor internal

\begin{tabular}{clccc}
\hline SIMBOL & \multicolumn{1}{c}{ FAKTOR } & BOBOT & RATING & SKOR \\
\hline S1 & $\begin{array}{l}\text { Monitoring Hutan Lindung dan badan air yang dilakukan oleh satgas } \\
\text { kodam III efektif. }\end{array}$ & 0,15 & 4 & 0,60 \\
S2 & $\begin{array}{l}\text { Timbul partisipasi masyarakat, baik secara inisiatif maupun inisiasi oleh } \\
\text { program pemerintah. }\end{array}$ & 0,17 & 4 & 0,68 \\
S3 & $\begin{array}{l}\text { Semakin banyak jumlah aktor kelompok crowd dan subject yang terlibat } \\
\text { dalam kelembagaan pengelolaan Sub DAS seiring dengan semakin }\end{array}$ & 0,17 & 4 & 0,68 \\
& kompleksnya permasalahan aspek biofisik. & & \\
W1 & Umumnya satgas Kodam III kurang bersinergi dengan masyarakat. & 0,09 & 2 & 0,18 \\
W2 & $\begin{array}{l}\text { Terjadi konflik lahan. } \\
\text { Kinerja komunitas umumnya efektif, namun wilayah kerjanya sempit } \\
\text { dan umumnya tidak dikenal warga. }\end{array}$ & 0,17 & 1 & 0,17 \\
W4 & Masyarakat merasa tidak memiliki kepentingan terhadap sungai. & 0,08 & 2 & 0,16 \\
\hline TOTAL & & 1,00 & & 0,17 \\
\hline
\end{tabular}

\section{Penilaian Faktor Internal dan Faktor Eksternal}

Penilaian faktor internal dan faktor eksternal dimulai dengan melakukan penilaian tingkat kepentingan dan pemberian rating serta pembobotan setiap faktor. Penilaian faktor internal tersajikan pada Tabel 6 dan penilaian faktor eksternal disajikan pada Tabel 7. 
Tabel 7. Penilaian skor faktor eksternal

\begin{tabular}{clccc}
\hline \multirow{2}{*}{ Simbol } & \multicolumn{1}{c}{ Faktor Eksternal } & Bobot & $\begin{array}{c}\text { Ratin } \\
\text { g }\end{array}$ & Skor \\
\hline O1 & $\begin{array}{l}\text { Mulai dirumuskan pembagian tupoksi lembaga secara detail } \\
\text { untuk menghindari permasalahan tumpang tindih }\end{array}$ & 0,15 & 4 & 0,60 \\
O2 & $\begin{array}{l}\text { Program RHL cukup berhasil membangun motivasi } \\
\text { ekonomi masyarakat dan meningkatkan kualitas lingkungan }\end{array}$ & 0,20 & 4 & 0,80 \\
O3 & $\begin{array}{l}\text { Kapal Api berencana membangun industri di Kecamatan } \\
\text { T1 }\end{array}$ & 0,22 & 4 & 0,88 \\
Kertasari & 0,09 & 1 & 0,09 \\
T2 & $\begin{array}{l}\text { Kinerja Forum DAS belum terlihat di tingkat tapak } \\
\text { Pengelolaan irigasi secara partisipatif kurang berjalan }\end{array}$ & 0,22 & 2 & 0,44 \\
& $\begin{array}{l}\text { Sulit terjadinya sinergis kerja antara Pemda dengan } \\
\text { kelompok lingkungan. }\end{array}$ & 0,12 & 2 & 0,24 \\
\hline & \multicolumn{1}{c}{ Total } & 1,00 & 3,05 \\
\hline
\end{tabular}

\section{Matriks Internal Factor Evaluation (IFE) \& External Factor Evaluation (EFE)}

Setelah melakukan penilaian bobot faktor strategis internal dan eksternal, selanjutnya adalah menentukan Matriks Internal-Eksternal (IE) yang didasarkan pada total skor EFE pada sumbu Y dan IFE pada sumbu X yang tertera pada Gambar 8.

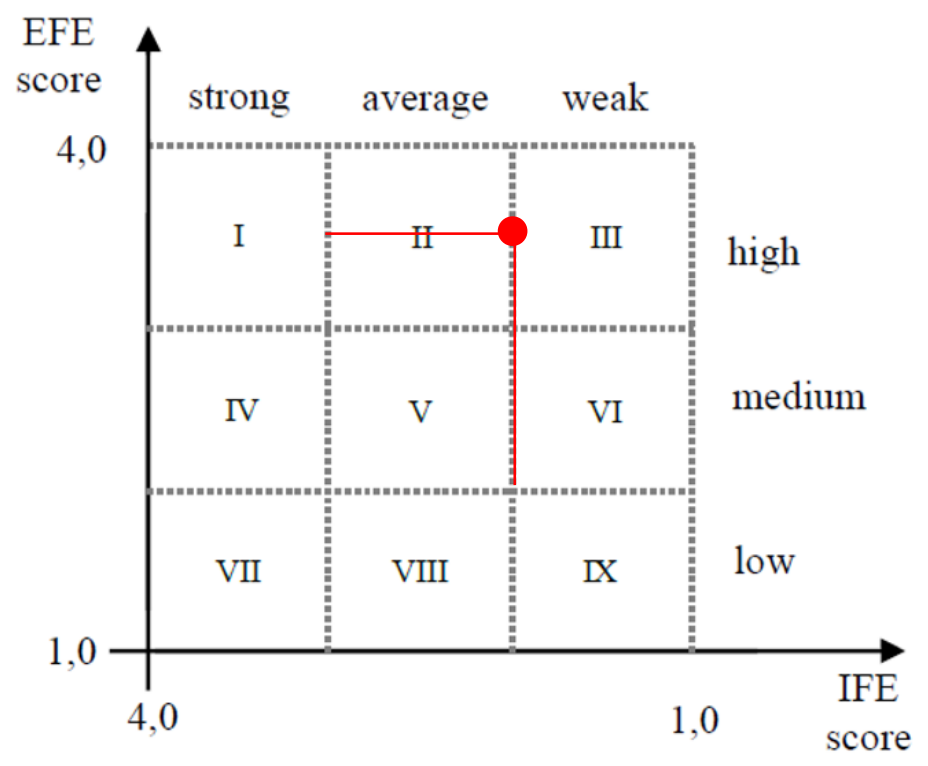

Gambar 8. Matriks Internal-Eksternal (IE)

\section{Matriks SWOT}

Pembuatan matriks SWOT dilakukan dengan saling mengaitkan unsur-unsur SWOT. Matriks SWOT menghasilkan empat macam strategi berdasarkan keterkaitan unsur SWOT. Empat macam strategi tersebut yaitu, strengths-opportunities
(SO), strengths-threats (ST), weaknessopportunities (WO), dan weakness-threats (WT). Berdasarkan keterkaitan unsur SWOT tersebut dihasilkan 7 alternatif strategi pengelolaan Sub DAS Cirasea berdasarkan sudut pandang kelembagaan. Hasil matriks SWOT disajikan pada Tabel 8. 
Tabel 8. Matriks SWOT

\begin{tabular}{|c|c|c|}
\hline & Opportunities & Threats \\
\hline Eksternal & 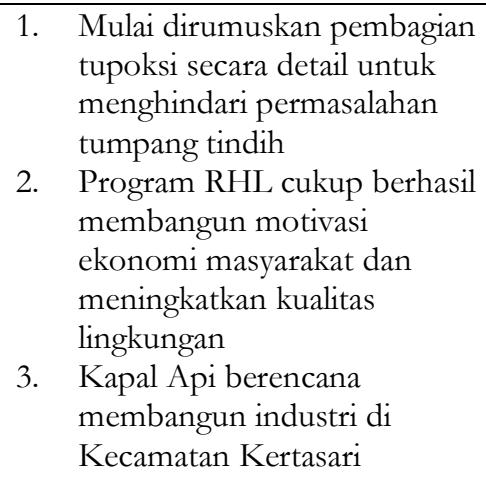 & $\begin{array}{l}\text { Kinerja Forum DAS belum } \\
\text { terlihat di tingkat tapak } \\
\text { 2. Pengelolaan irigasi secara } \\
\text { partisipatif kurang berjalan } \\
\text { 3. Sulit terjadinya sinergisitas } \\
\text { kerja antara Pemda dengan } \\
\text { kelompok lingkungan. }\end{array}$ \\
\hline Strengths & Strategi SO & Strategi ST \\
\hline $\begin{array}{l}\text { 1. } \begin{array}{l}\text { Monitoring Hutan Lindung } \\
\text { dan badan air yang dilakukan } \\
\text { oleh satgas kodam III efektif. }\end{array} \\
\text { 2. } \begin{array}{l}\text { Timbul partisipasi masyarakat, } \\
\text { baik secara inisiatif maupun } \\
\text { inisiasi oleh program } \\
\text { pemerintah. }\end{array} \\
\text { 3. Semakin banyak jumlah aktor } \\
\text { kelompok subject yang terlibat } \\
\text { dalam kelembagaan } \\
\text { pengelolaan Sub DAS seiring } \\
\text { dengan semakin kompleksnya } \\
\text { permasalahan aspek fisik. }\end{array}$ & 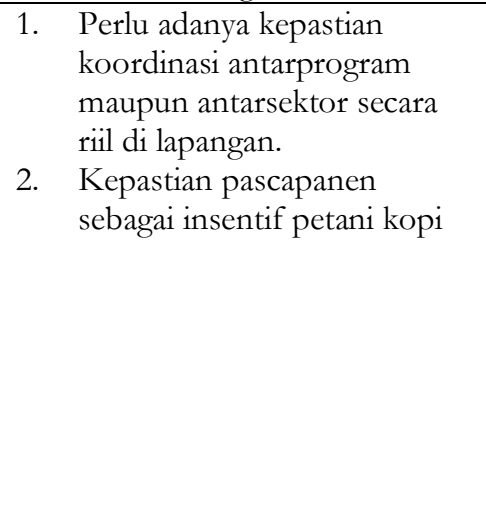 & $\begin{array}{l}\text { 1. Merevitalisasi Pengembangan } \\
\text { Perkumpulan Petani Pemakai } \\
\text { Air (P3A) program Mitra Cai } \\
\text { dan berkoordinasi dengan } \\
\text { kelompok lingkungan. }\end{array}$ \\
\hline Weakness & Strategi WO & Strategi W'T \\
\hline $\begin{array}{ll}\text { 1. } & \text { Umumnya satgas Kodam III } \\
\text { kurang bersinergi dengan } \\
\text { masyarakat dan komunitas } \\
\text { 2. } \\
\text { 3. } \\
\text { Kerjadi konflik lahan } \\
\text { efektif, namun wilayah kerjanya } \\
\text { sempit dan umumnya tidak } \\
\text { dikenal warga. } \\
\text { 4. } \\
\text { Masyarakat merasa tidak } \\
\text { memiliki kepentingan terhadap } \\
\text { sungai sehingga cukup sulit } \\
\text { melibatkan masyarakat dalam } \\
\text { pengelolaan Sub DAS. }\end{array}$ & 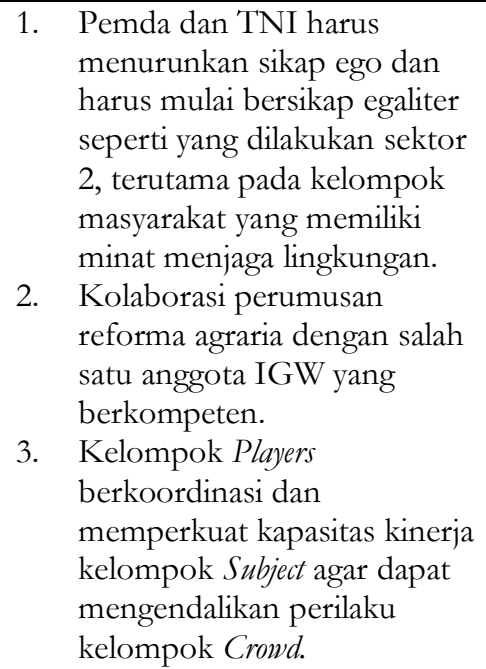 & $\begin{array}{l}\text { 1. Potensi ekonomi dan } \\
\text { semakin mudahnya } \\
\text { komoditas kopi diterima } \\
\text { masyarakat disekitar kawasan } \\
\text { hutan maupun non hutan } \\
\text { seharusnya dapat } \\
\text { menyatukan kepentingn } \\
\text { KLHK dan Kementan } \\
\text { beserta UPT } \\
\text { 2. Meningkatkkan SDM dan } \\
\text { pendanaan untuk } \\
\text { mengefektifkan kinerja } \\
\text { forum DAS dalam } \\
\text { memediasi kepentingan } \\
\text { antarsektoral }\end{array}$ \\
\hline
\end{tabular}

\section{Penentuan Peringkat Alternatif Strategi}

Peringkat alternatif strategi yang sudah dirumuskan ditentukan berdasarkan skor setiap alternatif strategi. Skor didapatkan dengan menjumlahkan seluruh skor faktor yang terkait dengan alternatif strategi. Peringkat alternatif strategi dapat menentukan strategi mana yang menjadi prioritas. Hasil peringkat alternatif strategi tercantum pada Tabel 9. 
Tabel 9. Peringkat alternatif strategi

\begin{tabular}{|c|c|c|c|c|}
\hline No & Alternatif Strategi & $\begin{array}{l}\text { Keterkaitan } \\
\text { Unsur SWOT }\end{array}$ & Skor & $\begin{array}{c}\text { Pering- } \\
\text { kat }\end{array}$ \\
\hline 1. & $\begin{array}{l}\text { Perlu adanya kepastian koordinasi antarprogram } \\
\text { maupun antarsektor secara riil di lapangan. }\end{array}$ & $\begin{array}{l}\text { S1, S2, S3 O1, } \\
\text { O2, O3 }\end{array}$ & 4,24 & 1 \\
\hline 2. & Kepastian pascapanen sebagai insentif petani kopi & $\mathrm{S} 1, \mathrm{~S} 2, \mathrm{~S} 3, \mathrm{O} 2$, & 3,64 & 2 \\
\hline 3. & $\begin{array}{l}\text { Kelompok Players berkoordinasi dan memperkuat } \\
\text { kapasitas kinerja kelompok Subject agar dapat }\end{array}$ & $\begin{array}{l}\text { O3 } \\
\text { W1, W3, W4 }\end{array}$ & 2,19 & 3 \\
\hline 4. & $\begin{array}{l}\text { mengendalikan perilaku kelompok Crowd. } \\
\text { Merevitalisasi Pengembangan Perkumpulan Petani }\end{array}$ & $\begin{array}{l}\mathrm{O} 2, \mathrm{O} 3 \\
\mathrm{~S} 2, \mathrm{~S} 3, \mathrm{~T} 2\end{array}$ & 1,80 & 4 \\
\hline 5. & $\begin{array}{l}\text { Pemakai Air (P3A) program Mitra Cai dan } \\
\text { berkoordinasi dengan kelompok lingkungan. } \\
\text { Pemda dan TNI harus menurunkan sikap ego dan }\end{array}$ & W1, O1 & 0,90 & 5 \\
\hline 6. & $\begin{array}{l}\text { harus mulai bersikap egaliter seperti yang dilakukan } \\
\text { sektor 2, terutama pada kelompok masyarakat yang } \\
\text { memiliki minat menjaga lingkungan. } \\
\text { Meningkatkkan SDM dan pendanaan untuk } \\
\text { mengefektifkan kinerja Forum DAS dalam memediasi } \\
\text { kepentingan antarsektoral di tingkat tapak. }\end{array}$ & $\begin{array}{l}\text { W1, W3, W4, } \\
\text { T1, T3 }\end{array}$ & 0,84 & 6 \\
\hline 7. & $\begin{array}{l}\text { Kolaborasi perumusan reforma agraria dengan salah } \\
\text { satu anggota IGW yang berkompeten. }\end{array}$ & W2, O1 & 0,77 & 7 \\
\hline 8. & $\begin{array}{l}\text { Potensi ekonomi dan semakin mudahnya komoditas } \\
\text { kopi diterima masyarakat disekitar kawasan hutan } \\
\text { maupun non hutan seharusnya dapat menyatukan } \\
\text { kepentingn KLHK dan Kementan beserta UPT } \\
\text { terkait. }\end{array}$ & W2, T1, T2 & 0,70 & 8 \\
\hline
\end{tabular}

\section{REFERENSI}

Bandaragoda, D.J. 2000. A framework for institutional analysis for water resources management in a river basin context. Working paper 5. Colombo (SL): International Water Management Institute.

Hasan, M. 2011. Model kebijakan pengelolaan sumber daya air pada Daerah Aliran Sungai (DAS) Citarum yang berkelanjutan. [Disertasi]. Bogor (ID): Institut Pertanian Bogor.

Prastiyo, Y.B., Kaswanto, R., Arifin, H.S. 2017. Analisis ekologi lanskap agroforestri pada riparian Sungai Ciliwung di Kota Bogor. Jurnal Lankap Indonesia. 2(9): 81-90.

Raharja, S.J. 2008. Pendekatan kolaboratif dalam pengelolaan Daerah Aliran Sungai Citarum. [Disertasi]. Depok (ID): Universitas Indonesia.
Rusdiana, O., Gufrona, R. 2011. Aplikasi model optimasi linear goals programming dalam menentukan pola penggunaan lahan optimal di DAS Citarum Hulu. JST. Vol. 02: 26-34.

Salampessy, M.L., Lidiawati, I. 2017. Potensi kelembagaan lokal dalam pengelolaan daeerah aliran sungai (studi kasus di Desa Cemplang, sub DAS Ciaten Hulu Timur DAS Cisadane). Jurnal Hutan tropis. 2(5): 113-11. 